\title{
Bovine Mastitis in Finland in 1988 and 1995 - Changes in Prevalence and Antimicrobial Resistance
}

\author{
By V. Myllys ${ }^{1}, K$. Asplund $^{1}$, E. Brofeldt ${ }^{4}$, V. Hirvelä-Koski ${ }^{1}$, T. Honkanen-Buzalski ${ }^{1}, J$. Junttila ${ }^{5}$, \\ L. Kulkas ${ }^{4}$, O. Myllykangas ${ }^{3}$, M. Niskanen ${ }^{1}$, H. Saloniemi ${ }^{2}$, M. Sandholm ${ }^{2}$ and T. Saranpä̈̈ ${ }^{1}$
}

${ }^{1}$ National Veterinary and Food Research Institute, ${ }^{2}$ Faculty of Veterinary Medicine, University of Helsinki, ${ }^{3}$ Maitohygienialiitto, ${ }^{4}$ Valio Oy, ${ }^{5}$ Veterinary and Food Department, Ministry of Agriculture and Forestry, Helsinki, Finland.

\begin{abstract}
Myllys V, Asplund K, Brofeldt E, Hirvelä-Koski V, Honkanen-Buzalski T, Junttila J, Kulkas L, Myllykangas O, Niskanen M, Saloniemi H, Sandholm M, Saranpää T: Bovine Mastitis in Finland in 1988 and 1995 - Changes in Prevalence and Antimicrobial Resistance. Acta Vet. Scand. 1998, 39, 119-126. - Two surveys were carried out (during 1988 and 1995) to estimate the prevalence of bovine mastitis in Finland. In 1988,17111 quarter milk samples were obtained from 4495 cows, and in 1995 the corresponding figures were 10410 and 2648. Antimicrobial susceptibility of mastitis pathogens was studied. Prevalence of mastitis on cow basis decreased from $47.8 \%$ in 1988 to $37.8 \%$ in 1995 . Staphylococci was the largest group of pathogens isolated. The proportion of Staphylococcus aureus decreased and that of coagulase-negative staphylococci (CNS) increased. The proportion of strains resistant to at least one antibacterial drug increased with regard to $S$. aureus from $36.9 \%$ in 1988 , to $63.6 \%$ in 1995 and with CNS from $26.6 \%$ to $49.7 \%$. Most of the increase in antibacterial resistance was due to a higher number of $\beta$-lactamase producing strains. Multiresistance also increased, but it was proportional to the overall increase in resistance. All the predominant mastitis streptococci were susceptible to $\beta$-lactams tested.
\end{abstract}

survey; antibiotic resistance; Staphylococcus.

\section{Introduction}

Finland has a long tradition of bovine mastitis control. The first formal control scheme was begun in the 1940's to eradicate contagious mastitis caused by Streptococcus agalactiae. As a result, the incidence of Str. agalactiaemastitis started to decrease and is now close to zero, but the incidence of mastitis caused by staphylococci, first by $S$. aureus and later by CNS, increased (Myllys et al. 1994). From 1978 , the mastitis control program was continued on voluntary basis by milk producers, the dairy industry, dairy advisers, and veterinarians. Despite the control program, the preva- lence of mastitis appeared to be increasing during the 1970's. In surveys carried out in 1975, the prevalence of mastitis was 33\% and in 1980 37\% (Koiranen 1976, Saloniemi 1980).

Another attempt by the Government of Finland to improve the quality of raw milk took place at the end of the 1980's. The Ministry of Agriculture and Forestry founded a committee with the purpose of decreasing the prevalence of mastitis. The committee consisted of experts on mastitis from the ministry, the College of Veterinary Medicine (currently the Faculty of Veterinary Medicine, University of Helsinki), the 
National Veterinary Institute (currently the National Veterinary and Food Research Institute), the dairy industry and the Finnish Veterinary Association. The committee proposed several measures to decrease the prevalence of mastitis including decrease in maximum acceptable bulk milk somatic cell count (SCC), quality premium for milk, training of veterinarians, dairy advisors, and milk producers on prevention of udder diseases, development of guidelines for diagnosis and treatment of mastitis, and preparation of teaching material. The committee also suggested that the dairy industry should employ veterinarians specialized in production animals and increase the number of dairy production advisors assisting the farmers in herd management to 1 advisor per 300 farms. Most of these aims have been met, and as a result the SCC of milk delivered to dairies has decreased during the 1990 's, being currently the lowest in the EU countries. In 1995, the geometric mean of bulk milk SCC was 132000 $/ \mathrm{ml}$.

The committee also suggested regular monitoring of the prevalence of mastitis. The first survey in 1988 was made on the initiative of the committee and the second in 1995 in cooperation with the National Veterinary and Food Research Institute and dairy industry. This paper describes the results of these prevalence surveys. Moreover, the antibacterial resistance of bovine mastitis pathogens is reported. The possible effect of the use of antimicrobials in mastitis therapy and prevention in relation of antibacterial resistance is also discussed.

\section{Materials and methods}

\section{Survey design}

In 1988, 33 dairy advisors from different areas of Finland were asked to select at random 2 milk collection routes in their working area and to collect quarter milk samples from all cows of all herds along the route. Quarter milk samples $(n=17111)$ were obtained from 4495 cows from 493 farms. In 1995, 280 dairy farms were selected randomly from all dairy farms in Finland (1994 data). Dairy advisors collected quarter milk samples from all cows at the farms that were stills producing milk. Quarter milk samples $(\mathrm{n}=10410)$ were obtained from 2648 cows from 238 farms.

\section{Sampling}

Quarter milk samples were collected aseptically. The teat ends were cleaned with alcohol (70\%) swabs and allowed to dry. After discarding the first few streams, the samples $(2-4 \mathrm{ml})$ were collected in sterile $10 \mathrm{ml}$ plastic tubes. Samples were cooled to $<+7^{\circ} \mathrm{C}$ and sent in cool bags with cold batteries to the National Veterinary and Food Research Institute - in 1988 either to Helsinki, Kuopio, Oulu or Seinäjoki and in 1995 only to Helsinki. Another nonaseptic sample of $40 \mathrm{ml}$ was drawn into a $40 \mathrm{ml}$ plastic tube for SCC measurement from each quarter. The samples were cooled and in the 1988 survey sent to individual dairy laboratories and in 1995, to a dairy laboratory in Helsinki.

\section{Analysis of milk samples}

Inflammatory parameters: SCC was estimated on the farms by the dairy advisors using the Californian Mastitis Test (CMT) with a scale of 1-5 (Klastrup 1975) and accurately measured using Fossomatic (Foss Electric, Hillerod, Denmark). $\mathrm{N}$-acetyl- $\beta$-glucosaminidase (NAGase) activity of the samples was determined after 1 cycle of freezing and thawing. The fluorogenic NAGase assay system (Mattila 1984) was used with a Fluoroskan I microtitration tray fluorometer (Labsystems, Helsinki, Finland), and the results were expressed in arbitrary units (U).

Bacteriology: Samples were cultured by streaking out $10 \mu \mathrm{l}$ of milk with a sterile cali- 
brated plastic loop on Trypticase Soy Agar plates (BBL, Cockeysville, MD, USA) containing $5 \%$ bovine blood. Bacterial species were identified using routine bacteriological methods (Klastrup 1975, Honkanen-Buzalski \& Seuna 1995).

Susceptibility testing: $\beta$-lactamase testing was performed in 1988 using Beta-lactam tablets (Rosco, Taastrup, Denmark) and in 1995 using liquid nitrocefin (Becton Dickinson Microbiology Systems, Cockeysville, USA) immediately after isolation. The bacterial isolates were stored at $-70^{\circ} \mathrm{C}$ using Protect Bacterial Preservers (Technical Service Consultants LTD, Heywood Lancs, UK) until further analysis. Antibacterial susceptibility testing was performed on randomly selected isolates using the agar diffusion method. In 1988, Rosco tablets and Müller Hinton agar were used, in 1995 Oxoid tablets and IsoSensitest Agar. Interpretation of the test results was done similarly based on NCCLS (Anonymous 1994) criteria.

\section{Data analysis}

In the 1988 material, a cow was diagnosed as having mastitis if the CMT score from at least 1 quarter was 3 or higher and, in the 1995 material, if the SCC from at least 1 quarter exceeded $300000 / \mathrm{ml}$ (Klastrup \& Schmidt Madsen 1974). Somatic cell count results were not used in the 1988 survey because of a large number of missing samples and variation between laboratories. In the cases where samples for the SCC measurement were not obtained in the 1995 survey $(n=232)$, a NAGase value of 23 , which corresponded in this material to an $\mathrm{SCC}$ value of $300000 / \mathrm{ml}$, was used as a threshold value. Data from cows that were about to be dried-off and yielded less than 5 liters of milk/day were not included in the results. The data were analysed using the statistical software package SAS (SAS Inst., Inc., Cary, NC, USA) in 1988 and Statistix (Analytical Software, St. Paul, MN, USA) in 1995.

\section{Results}

The prevalence of bovine mastitis decreased from $47.8 \%$ in 1988 (95\% confidence interval $44.1-50.1)$ to $37.8 \%$ in 1995 (95\% confidence interval 35.1-40.5) (Fig. 1). The proportion of quarters producing low cell count milk increased during the study period (Fig. 2). The results of bacteriological findings are summarized in Table 1. Staphylococci were the largest group of pathogens involved. The proportion of $S$. aureus decreased and that of the CNS increased. Also, the proportion of coryneforms, mostly $C$. bovis, increased.

The proportion of bacterial isolates resistant to at least one antibacterial drug (mostly penicillin) increased among $S$. aureus isolates from $36.9 \%$ in 1988 to $63.6 \%$ in $1995(\mathrm{p}<0.001)$ and in CNS from $26.6 \%$ to $49.7 \%(\mathrm{p}<0.001)$, respectively (Table 4). Multiresistance also increased, but the increase was proportional to the total increase in resistance (Table 4). Of the staphylococci, CNS were more often susceptible to all antibacterials than $S$. aureus, but resistant CNS isolates were more often multiresistant than $S$. aureus isolates (Table 4). The most common form of multiresistance in $S$. aureus and CNS was resistance to penicillin, tetracycline and sometimes also to neomycin. Resistance to penicillin, erythromycin, and sometimes also to trimethoprim-sulpha, was recorded for CNS. Results of antimicrobial susceptibility tests are summarized in Tables 2 and 3.

In $1988, \beta$-lactamase was produced by $32.1 \%$ of the.S. aureus strains $(n=340)$ and $12,1 \%$ of the CNS strains $(\mathrm{n}=231)$. The corresponding figures in 1995 were $50.7 \%(n=373)$ for $S$. aureus and $34.1 \%(\mathrm{n}=1166)$ for CNS. The results of $\beta$-lactamase tests from 1988 were not analyzed further, because the results of the acido- 


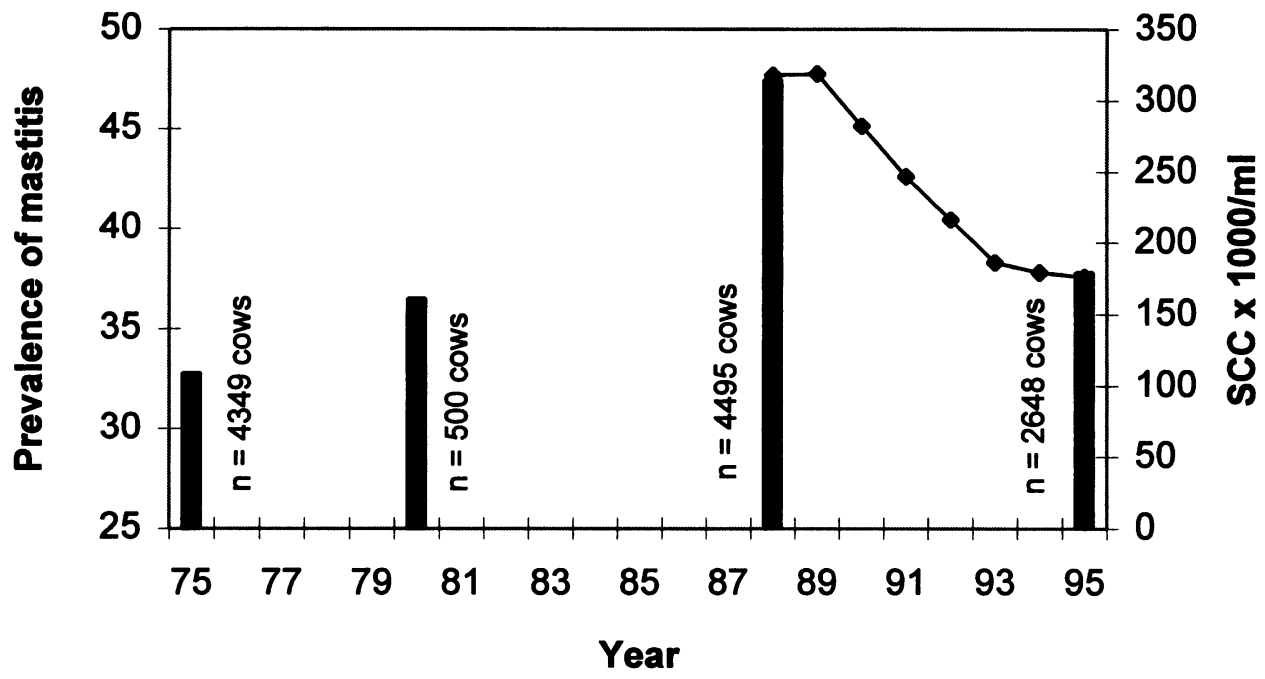

Figure 1. Development of mastitis prevalence (bars) according to surveys $(1975,1980,1988$ and 1995) and annual change of arithmetic mean SCC of milk delivered to dairies (line) between 1988 and 1995 in Finland.

metric test are not comparable with those of the nitrocefin test. Based on the results of the 1995 survey, in $75 \%$ of the farms where $S$. aureus bacteria were isolated from mastitic cows, all isolates were either $\beta$-lactamase positive or negative. In only $25 \%$ of farms, both $\beta$-lactamase positive and negative isolates were found. With CNS the corresponding figures were $39 \%$ and $61 \%$. In individual farms, production of $\beta$-lactamase both by $S$. aureus and CNS was not statistically correlated.

\section{Discussion}

One of the most important findings in these surveys was that the prevalence of mastitis has started to decrease, and in 1995 the proportion

Table 1. Bacterial isolates found during the surveys. Figures in first column each year are percentages of quarter samples, and in second column proportional percentages of bacterial isolates.

\begin{tabular}{lcccrc}
\hline & \multicolumn{2}{c}{1988} & & \multicolumn{2}{c}{1995} \\
\cline { 2 - 3 } \cline { 5 - 6 } & $\mathrm{n}=16970$ & $\mathrm{n}=2803$ & & $\mathrm{n}=10337$ & $\mathrm{n}=2172$ \\
\hline Str. agalactiae & 0.78 & 4.71 & & 0.12 & 0.55 \\
Str. dysgalactiae & 0.79 & 4.78 & & 0.08 & 0.37 \\
Str. uberis & 1.18 & 7.14 & & 0.72 & 3.41 \\
Other streptococci a) & 0.87 & 5.28 & & 1.44 & 6.86 \\
S. aureus & 5.12 & 31.00 & & 3.50 & 16.67 \\
CNS & 6.57 & 39.78 & & 11.24 & 53.50 \\
Coryneforms & 0.82 & 4.99 & & 3.49 & 16.62 \\
Coliforms & 0.26 & 1.57 & & 0.29 & 1.38 \\
Other bacteria & 0.12 & 0.75 & & 0.14 & 0.64 \\
No bacteria & 83.48 & & 78.99 & \\
\hline
\end{tabular}

a) E. faecalis and E. faecium included. 


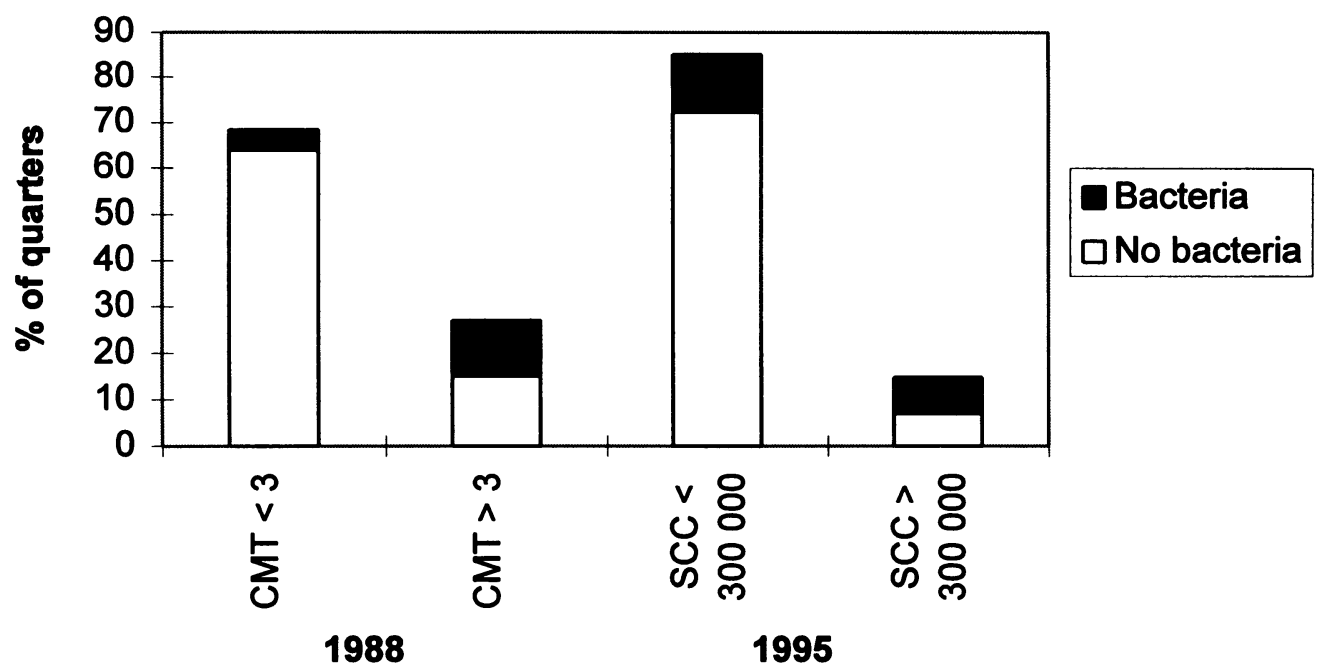

Figure 2. Distribution of healthy and inflamed quarters with or without bacteria in surveys during 1988 and 1995.

of quarters producing low cell count milk was high. The decrease has been $1.5 \%$ per year on average. This was a welcome change to the gradual increase in mastitis prevalence noted in surveys from 1975 to 1988 . This new trend was expected. According to the statistics the arithmetric mean SCC of bulk milk delivered to dairies has decreased gradually during the 1990's (Fig. 1). Mastitis prevalence of $47.8 \%$ and $37.8 \%$ might appear high, but the criteria for mastitis were quite strict in these surveys.
According to IDF criteria, a threshold of 500 000 cells $/ \mathrm{ml}$ should be used (Anonymous 1987). If the IDF criteria were used in the 1995 survey, the prevalence of mastitis in cows would have been $27.9 \%$ (95\% confidence interval 25.2-30.6). In the 1995 survey, mastitis prevalence was $35.7 \%$ (95\% confidence interval 32.6-38.8) using criteria based on CMT. This was not statistically different from prevalence based on SCC data. The results of these surveys should therefore be comparable even

Table 2. Proportion of staphylococcal strains susceptible to antimicrobials in 1988 and 1995.

\begin{tabular}{|c|c|c|c|c|}
\hline & \multicolumn{2}{|c|}{ S. aureus } & \multicolumn{2}{|c|}{ CNS } \\
\hline & $\begin{array}{c}1988 \\
n=344\end{array}$ & $\begin{array}{c}1995 \\
\mathrm{n}=154\end{array}$ & $\begin{array}{c}1988 \\
n=237\end{array}$ & $\begin{array}{c}1995 \\
\mathrm{n}=183\end{array}$ \\
\hline Cephalothin & 99.7 & 98.0 & 99.1 & 97.3 \\
\hline Erythromycin & 95.9 & 97.4 & 90.7 & 88.5 \\
\hline Enrofloxacin & 99.7 & 100.0 & 99.1 & 98.9 \\
\hline Neomycin & 98.8 & 96.7 & 97.5 & 97.3 \\
\hline Oxacillin & 98.5 & 100.0 & 98.7 & 99.4 \\
\hline Penicillin-G & 68.2 & 49.3 & 75.9 & 62.8 \\
\hline Tetracyclines & 93.0 & 88.3 & 89.9 & 90.2 \\
\hline Trimethoprim-sulphonamide & 99.4 & 100.0 & 100.0 & 91.7 \\
\hline
\end{tabular}


Table 3. Proportion of streptococcal strains susceptible to antimicrobials in 1995.

\begin{tabular}{|c|c|c|}
\hline & $\begin{array}{c}\text { Str. agalactiae } \\
\text { Str. dysgalactiae } \\
\text { Str. uberis } \\
\mathrm{n}=72\end{array}$ & $\begin{array}{c}\text { Str. spp }{ }^{\mathrm{a})} \\
\mathrm{n}=48\end{array}$ \\
\hline Ampicillin & 100.0 & 54.2 \\
\hline Cephalothin & 100.0 & 43.8 \\
\hline Erythromycin & 98.6 & 83.3 \\
\hline Enrofloxacin & 93.0 & 83.3 \\
\hline Neomycin & 0.0 & 0.0 \\
\hline Oxacillin & 100.0 & 33.3 \\
\hline Penicillin-G & 100.0 & 47.9 \\
\hline Tetracycline & 90.3 & 62.5 \\
\hline $\begin{array}{l}\text { Trimethoprim- } \\
\text { sulphonamide }\end{array}$ & 61.1 & 35.4 \\
\hline
\end{tabular}

a) E. faecalis and E. faecium included.

though mastitis prevalence in the 1988 survey was estimated using criteria based on CMT and in 1995 on SCC measurement.

Another important change was the decrease of $S$. aureus isolates, while the proportion of CNS and coryneforms increased. Not all the factors affecting bacterial ecology of mastitis pathogens are clear. However, culling of chronic $S$. aureus cows has been one successful way of decreasing $S$. aureus prevalence during recent years. Probably the decrease in prevalence in general and decrease in the prevalence of $S$. au- reus mastitis in particular were connected. $S$. aureus is known to cause chronic subclinical mastitis, which increases SCC. The measures suggested by the mastitis committee at the end of 1980's have influenced the decrease in mastitis prevalence. Even if it is not possible to estimate the effect of individual measures, quality premium must have been among the most effective ones. Factors that may alter the distribution of bacterial species of bovine mastitis are the use of antibacterials (Myllys et al. 1994, Ferns et al. 1991), teat dips (Langlois et al. 1990), low SCC in milk (Erskine et al. 1988) and environmental conditions of the cows (Schukken et al. 1991).

The role of CNS as a cause of bovine mastitis is not completely clear. On the one hand, CNS have been shown to elevate the SCC, thus decreasing milk yield and quality of milk, and on the other hand CNS are reported to prevent infections caused by other pathogens (Matthews et al. 1990, Matthews et al. 1991, Nickerson \& Boddie 1994). Currently most infections caused by CNS are mild and more easily cured than infections caused by S. aureus (Pyörälä \& Pyörälä 1994). Staphylococci are divided into 32 species and subspecies, most of which are coagulase negative. Only a limited number of species was regularly isolated from clinical cases (Honkanen-Buzalski et al. 1994). With

Table 4. Resistance in staphylococci (cephalothin, erythromycin, enrofloxacin, neomycin, oxacillin, penicillin-G, tetracycline and trimethoprim-sulphonamide) in 1988 and 1995.

\begin{tabular}{lccccc}
\hline & \multicolumn{2}{c}{ S. aureus } & & \multicolumn{2}{c}{ CNS } \\
\cline { 2 - 3 } \cline { 5 - 6 } & $\begin{array}{c}1988 \\
\mathrm{n}=344 \\
\%\end{array}$ & $\begin{array}{c}1995 \\
\mathrm{n}=154 \\
\%\end{array}$ & & $\begin{array}{c}1988 \\
\mathrm{n}=223 \\
\%\end{array}$ & $\begin{array}{c}1995 \\
\mathrm{n}=183 \\
\%\end{array}$ \\
\hline Susceptible to all antibacterials & 63.1 & 36.4 & & 73.4 & 50.3 \\
Resistant to 1 antibacterial & 32.5 & 52.0 & & 15.6 & 30.6 \\
Resistant to 2 antibacterials & 3.2 & 8.4 & & 6.8 & 12.0 \\
Resistant to 3 antibacterials & 0.9 & 3.2 & & 3.4 & 4.9 \\
Resistant to 4 antibacterials & 0.3 & 0.0 & & 0.8 & 2.2 \\
\hline
\end{tabular}


more comprehensive knowledge, CNS could in the future be divided into pathogenic and commensal species enabling mastitis caused by CNS to be handled more appropriately.

Most of the increase in antibacterial resistance between 1988 and 1995 was due to higher numbers of $\beta$-lactamase producers. Currently the proportion of resistant staphylococci is much higher in Finland than in other Nordic countries. The most probable reason for this has been the use of antibacterials in Finland. In the 1980 's, mastitis therapy was based mainly on the use of broad spectrum antimicrobials. At the beginning of the 1990 's, this practice was replaced with more common use of narrow spectrum antimicrobial therapy, based on bacterial isolation and susceptibility testing. In this process, the use of tetracyclines has markedly decreased, and use of intramammaries containing combinations of betalactams and aminoglycosides has increased. The most commonly used beta-lactams in dry-cow therapy are cephalosporins and in lactational therapy cephalosporins and penicillin-G.

CNS may represent a reservoir of resistance genes to $S$. aureus (Archer \& Climo 1994). This may become apparent when large quantities of antibacterials are used to control $S$. aureus mastitis including intensive therapy and regular dry-cow therapy. In this study, $\beta$-lactamase positive $S$. aureus isolates were not more prevalent on farms where $\beta$-lactamase positive CNS isolates were dominating, indicating that $\mathrm{CNS}$ were not a major reservoir of resistance to $S$. aureus. A finding causing some concern was that CNS were quite often resistant to several antibacterials. Also, in other studies CNS have been more frequently resistant to antibacterials than S. aureus (Hodel Christian \& Murray 1992, Owens \& Watts 1988). As the prevalence of CNS mastitis seems to be increasing, the resistant CNS strains may become a serious clinical problem.
All isolates of Str. agalactiae, Str. dysgalactiae and Str. uberis were susceptible to all $\beta$-lactams tested, and resistance was not a clinical problem. This was also seen as a decrease in prevalence of mastitis caused by predominant mastitis streptococci in 1995. Penicillin is still the drug of choice for treating infections caused by these bacteria. Other streptococci and enterococci, however, were resistant to a multitude of antibacterials and if treatment is needed in such cases, it should be based on the results of susceptibility testing.

\section{References}

Anonymous: Bovine mastitis. Definition and guidelines for diagnosis. Bulletin of IDF, 1987, 211, $1-24$.

Anonymous: Performance standards for antimicrobial disk and dilution susceptibility tests for bacteria isolated from animals; proposed standard. NCCLS Document M31-P, 1994, 14, 45 pp.

Archer GL, Climo MW: Antimicrobial susceptibility of coagulase-negative staphylococci. Antimicrob. Agents Chemother. 1994, 38, 2231-2237.

Erskine RJ, Eberhart RJ, Hutchinson LJ, Spencer SB, Campbell MA: Incidence and types of clinical mastitis in dairy herds with high and low somatic cell counts. J. Am. Vet. Med. Assoc. 1988, 192, 761-765.

Ferns L, Dohoo I, Donald A: A case-control study of Nocardia mastitis in Nova Scotia dairy herds. Can. Vet. J. 1991, 32, 673-677.

Hodel Christian SL, Murray BE: Comparison of the gentamicin resistance transposon $\operatorname{Tn} 5281$ with regions encoding gentamicin resistance in Enterococcus faecalis isolates from diverse geographic locations. Antimicrob. Agents Chemother. 1992, 36, 2259-2264.

Honkanen-Buzalski T, Myllys V, Pyörälä S: Bovine clinical mastitis due to coagulase-negative staphylococci and their susceptibility to antimicrobials. J. Vet. Med. B. 1994, 41, 344-350.

Honkanen-Buzalski T, Seuna E: Isolation and identification of pathogens from milk. In: M Sandholm, T Honkanen-Buzalski, L Kaartinen \& S Pyörälä (eds): The bovine udder and mastitis. Gummerrus kirjapaino Oy, Jyväskylä, Finland, 1995, p. 121-141. 
Klastrup O, Schmidt Madsen: Nordiske rekommendationer verdrøende mastitundersøgelser af kiertelprøver. Nord. Vet. Med. 1974, 26, 197 204.

Klastrup NO: Scandinavian recommendations on examination of quarter milk samples. IDF Annu. Bull. 1975, 85, 49-52.

Koiranen L: Utaretulehduksen yleisyys Suomessa. (Prevalence of mastitis in Finland). Finnish Vet. J. 1976, 82, $64-72$.

Langlois BE, Parlindungan AK, Harmon RJ, Akers $K$ : Biochemical characteristics of Staphylococcus species of human and bovine origin. J. Food Prot. 1990, 53, 119-126.

Matthews KR, Harmon RJ, Smith BA: Protective effect of Staphylococcus chromogenes infection against Staphylococcus aureus infection in the lactating bovine mammary gland. J. Dairy Sci. 1990, 73, 3457-3462.

Matthews KR, Harmon RJ, Langlois BE: Effect of naturally occuring coagulase-negative staphylococci infections on new infections by mastitis pathogens in the bovine. J. Dairy Sci. 1991, 74, 1855-1859.

Mattila T: Diagnostic problems in bovine mastitis. Thesis, College of Veterinary Medicine Helsinki Finland 1984, $100 \mathrm{pp}$.

Myllys V, Honkanen-Buzalski T, Huovinen P, Sandholm M, Nurmi E: Association of changes in the bacterial ecology of bovine mastitis with changes in the use of milking machines and antibacterial drugs. Acta Vet. Scand. 1994, 35, 363-369.

Nickerson SC, Boddie RL: Effect of naturally occuring coagulase-negative staphylococcal infections on experimental challenge with major mastitis pathogens. J. Dairy Sci. 1994, 77, 2526-2536.

Owens WE, Watts JL: Antimicrobial susceptibility and B-lactamase testing of staphylococci isolated from dairy herds. J. Dairy Sci. 1988, 71, 19341939.
Pyörälä S, Pyörälä E: Efficacy of bovine clinical mastitis therapy during lactation. Proceedings and Abstracts XVII. Nordic Veterinary Congress. The Icelandic Veterinary Association; Reykjavik, Iceland. 1994, p. 42-45.

Saloniemi $H$ : Udder diseases in dairy cows - field observations on incidence, somatic and environmental factors, and control. J. Sci. Agric. Soc. Finland 1980, 52, 85-184.

Schukken YH, Grommers FJ, Van de Geer D, Erb HN, Brand A: Risk factors for clinical mastitis in herds with a low bulk milk somatic cell count. 2 . Risk factors for Escherichia coli and Staphylococcus aureus. J. Dairy Sci. 1991, 74, 826-832.

\section{Sammanfattning}

Mastit hos kor under åren 1988 och 1995 - Förändring av prevalens och antibiotika resistens.

Två undersökningar utfördes (under åren 1988 och 1995) för att beräkna förekomsten av mastit i Finland. År 1988 togs mjölkprov från 17111 juverfjärdedelar av sammanlagt 4495 kor. År 1995 var motsvarande antal 10410 och 2648. Man undersökte mastitpatogenernas känslighet mot antibiotika. Mastit prevalensen minskade från $47.8 \% 1988$ till $37.8 \%$ 1995. Stafylokockerna utgjorde den största gruppen av isolerade patogener. Antalet Staphylococcus aureus minskade medan de koagulas-negativa stafylokockerna (CNS) ökade. Stammar som var resistenta mot åtminstone ett antibiotikum ökade med avseende på $S$. aureus från $36.9 \% 1988$ till $63.6 \% 1995$ och med avseende på CNS från $26.6 \%$ till $49.7 \%$. Ökningen $\mathrm{i}$ antimikrobiresistens berodde främst på ett högre antal $\beta$-lactamasproducerande stammar. Även resistensen mot flera antimikrobiella medel ökade, men motsvarade proportionellt sett den allmänna ökningen av resistens. De främsta mastitstreptokokkerna var känsliga för de $\beta$-lactamer som testades.

(Received August 15, 1996; accepted December 1, 1997).

Reprints may be obtained from: V. Myllys, National Veterinary and Food Research Institute, Box 368, FIN00231 Helsinki, Finland. E-mail: vesa.myllys@eela.fi, tel: +358 93931850 , fax: +358 93931811. 